\title{
INDUSTRIALISASI VAGINA: POTRET KEBIJAKAN PELACURAN
}

\author{
Abas \\ Program Studi Administrasi Publik, Fakultas Ilmu Sosial dan Politik, Universitas Bandar Lampung, \\ ab3_male@yahoo.com
}

\begin{abstract}
Abstrak
Isu tentang pelacuran telah ada jauh sebelumnya, yang diyakini telah dimulai sejak masa perbudakan. Bahkan pelacuran sebagai sebuah pekerjaan seringkali disebut sebagai salah satu jenis pekerjaan tertua di Dunia. Meskipun beberapa kelompok Feminis sebelum tahun 1980an dengan meyakinkan mengatakan bahwa prostitusi adalah pertanda dan contoh subordinasi perempuan yang tidak akan ada lagi saat wanita mendapatkan persamaan (Jefrey 2009). Seperti Millett katakan, bentuk lama 'fosil hidup' hubungan budak masih ada pada saat ini (Millet 1975). Bahkan Sheila Jeffrey (2009) mengatakan bahwa apa yang terpenting saat ini bahwasanya ideologi dan praktik ekonomi baru saat ini, yakni "Neo-liberalisme", di mana toleransi 'kebebasan seksual' telah digabungkan dengan ideologi pasar bebas untuk merekonstruksi pelacuran sebagai 'pekerjaan' yang sah yang bisa menjadi dasar industri seks nasional dan internasional. Karenanya, perkembangan sektor ini perlu dipahami sebagai komersialisasi dari subordinasi perempuan, dan menunjukkan bagaimana kembalinya industri seks global bisa dimulai.
\end{abstract}

Kata Kunci: Etika, Tata Kelola Pemerintahan

\begin{abstract}
The issue of prostitution has long existed before, which is believed to have begun since the period of slavery. Even prostitution as a work is often referred to as one of the oldest types of work in the World. Although some Feminist groups before the 1980s convincingly said that prostitution is a sign and a subordinate example of women that will not exist anymore when women get the equation (Jefrey 2009). As Millett puts it, the old form of 'living fossils' of slave relations still exists today (Millet 1975). Even Jeffrey (2009) says that what is most important today is that the current ideology and new economic practice, "Neo-liberalism," in which the tolerance of 'sexual liberty' has been combined with free market ideology to reconstruct prostitution as 'work' law that could be the basis of the national and international sex industry. Therefore, the development of this sector needs to be understood as the commercialization of the subordination of women, and shows how the return of the global sex industry can begin.
\end{abstract}

Keywords: Ethics, Governance

\section{PENDAHULUAN}

Sebagian besar pelacuran berada di dalam negaranegara barat yang disahkan dan di seluruh dunia tetap menjadi ilegal dan sektor yang paling menguntungkan bagi kejahatan terorganisir (Jeffrey, 2009). Bahkan terdapat perubahan dalam penggunaan Bahasa pelacuran untuk memperhalus dan melegalkan praktik ini, melalui mekanisme kerja industri. Dalam kerangka feminis radikal, pelacuran, adalah menjadi praktik budaya yang berbahaya yang berasal dalam subordinasi perempuan (Jeffreys, 2004) dan merupakan sebuah bentuk kekerasan terhadap perempuan (Jeffreys, 1997). Sejak tahun 1970an telah terjadi perkembangan yang cukup besar dalam pengakuan atas apa yang disebut di dalam dokumen Perserikatan Bangsa-Bangsa sebagai 'Praktik tradisional / budaya yang berbahaya' (Jeffreys, 2005).

Kata-kata tradisional dan budaya digunakan secara bergantian di literatur PBB tentang hal ini. Perkembangan ini merupakan hasil kampanye feminism dan dimulai dengan kekhawatiran tentang mutilasi genital wanita, yang bisa dianggap secara paradigmatik 'praktik budaya yang berbahaya'. Perhatian ini telah ditulis pada tahun 1979 melalui United Nations Convention on the Elimination of all Forms of Discrimination Against Women (CEDAW), yakni Konvensi Bangsa tentang Penghapusan Segala Bentuk Diskriminasi terhadap Wanita.

Pasal 2 (f) CEDAW menyatakan bahwa para pihak dalam Konvensi akan 'mengambil semua tindakan yang tepat, termasuk undang-undang, untuk memodifikasi atau menghapus undang-undang, peraturan, kebiasaan dan praktik yang merupakan diskriminasi terhadap wanita. Pasal 5 (a) juga menyatakan bahwa semua tindakan yang sesuai akan diambil untuk memodifikasi pola perilaku pria dan wanita, sosial dan budaya dengan tujuan untuk mencapai penghapusan prasangka dan kebiasaan dan semua praktik lainnya yang didasarkan pada gagasan inferioritas atau superioritas salah satu jenis kelamin atau peran stereotip untuk pria dan wanita.

Banyak praktik budaya yang berbahaya diakui di dunia internasional berawal dari pertukaran perempuan. Pertukaran perempuan diantara pria untuk tujuan seksual 
dan akses reproduksi dan untuk mengekstrak tenaga kerja bebas adalah dasar dari subordinasi perempuan, dan masih berakar kuat dalam budaya patriarki (Rubin, 1975). Sebagaimana Jeffrey (2009) katakan bahwa dalam dua dekade terakhir bahasa yang digunakan dalam literatur akademis dan dalam formasi kebijakan telah berubah secara signifikan sebagaimana pelacuran telah dinormalisasi. Bahkan sarjana feminis dan aktivis sekarang umumnya menggunakan bahasa eufemistik baru, sesuai dengan pemahaman yang dipromosikan oleh beberapa kelompok advokat kerja seks di tahun 1980-an, di mana pelacuran biasanya disebut saat ini sebagai 'pekerja seks', yang menunjukkan bahwa hal itu harus dilihat sebagai bentuk yang sah dari sebuah pekerjaan (Jeffreys, 1997; Jeness, 1993).

Posisi kerja seks adalah dasar dari tuntutan untuk normalisasi dan legalisasi prostitusi. Sebagai akibat wajar dari posisi ini, pria yang membeli wanita sekarang sering disebut sebagai 'klien', yang menormalkan praktik mereka hanya sebagai bentuk aktivitas konsumen lainnya sebagaimana umumnya dalam bahasa ekonomi. Mereka yang menjalankan tempat prostitusi dan mengambil keuntungan dari industri secara teratur disebut "penyedia layanan”, ini seperti misalnya terlihat di negara bagian di Victoria, Australia, di mana keberadaan rumah pelacuran yang diatur oleh Otoritas Perizinan Bisnis, sebagai 'penyedia layanan' (M. Sullivan, 2007).

Pada tahun 1990-an, bahasa yang berkaitan dengan perdagangan perempuan menjadi pelacuran juga telah diubah oleh mereka yang menganggap pelacuran sebuah sektor pasar biasa. Penggunaan bahasa itu penting sebagai bahasa perdagangan biasa dalam kaitannya dengan prostitusi dan membuat bahaya praktik ini tidak terlihat. Ini sekaligus memfasilitasi pengembangan yang menguntungkan dari industri global. Karenanya, jika ada kemajuan yang harus dicapai maka bahasa yang membuat kerugian juga harus terlihat, dipertahankan atau dikembangkan. Karenanya, Jeffrey (2009) telah mengusulkan penggunaan bahasa pelacur sebagai wanita yang dilacurkan daripada pekerja seks, karena ini menunjukkan bahwa ada sesuatu yang berbahaya yang sedang dilakukan.

Sedangkan sebutan yang tepat bagi laki-laki adalah prostitutor----pembeli pelacur, bukan klien. Perantara, dapat disebut sebagai mucikari (pimps dan procurers), istilah yang sekarang mungkin tampak kuno tapi yang menunjukkan penghinaan yang masuk akal untuk mereka yang mengambil keuntungan turunan dari rasa sakit yang dirasakan oleh wanita yang dilacurkan. Sedangkan negara yang melegalkan industri prostitusi dapat disebut sebagai 'negara germo'.

Sebagian besar bentuk penyalahgunaan wanita lokal dan sosial yang diremehkan menjadi sangat menguntungkan dan baik legal atau ditoleransi melalui industri internasional. Bahkan di negara bagian yang telah melegalisasi industri pelacuran, industri rumah bordil skala besar mempekerjakan ratusan wanita, diawasi dan diatur oleh instansi pemerintah (Sullivan, 2007). Di beberapa negara di Asia, industrialisasi pelacuran terjadi dalam bentuk penciptaan prostitusi massif Di daerah kota. Di Daulatdia, terbentuk 20 tahun yang lalu, di sebuah pelabuhan Kota di Bangladesh, 1.600 wanita digunakan secara seksual oleh 3.000 pria setiap hari (Hammond, 2008). Kathleen Barry menjelaskan bahwa, sejak tahun 1970, 'yang paling dramatis bahwa perubahan prostitusi telah menjadi industrialisasi, normalisasi, dan penyebaran global yang meluas.

Hasil industrialisasi adalah 'pasar global bernilai miliaran dolar bagi perempuan, di dalam dan luar negeri, perdagangan yang sangat terorganisir dan dalam pengaturan informal yang paling beragam' (Barry, 1995). Sebuah laporan Organisasi Buruh Internasional (ILO) tahun 1998, menunjukkan bukti kuat bahwa prostitusi diselenggarakan di atas sebuah skala yang cukup baru dan terintegrasi ke dalam ekonomi nasional secara signifikan. Seperti komentar Lim, bahwa: "Pelacuran telah berubah baru-baru ini di beberapa negara Asia Tenggara. Skala prostitusi telah diperbesar sampai batas tertentu dimana kita dapat dibenarkan berbicara tentang sektor seks komersial yang diintegrasikan ke dalam kehidupan ekonomi, sosial dan politik dari negara-negara ini. Bisnis seks telah mengasumsikan dimensi dari sebuah industri dan secara langsung atau tidak langsung memberikan kontribusi yang kecil untuk pekerjaan, pendapatan nasional dan pertumbuhan ekonomi (Lim, 1998: vi)

Laporan ILO memperkirakan bahwa industri seks menyumbang 2-14 persen dari nilai ekonomi di empat negara yang telah diteliti, yaitu Filipina, Malaysia, Thailand dan Indonesia (Moon, 1997; Tanaka, 2002). Pemerintah Korea memperkirakan pada tahun 2002 bahwa satu juta wanita berada dalam pelacuran di negara tersebut (Hurt, 2005). Industri ini diperkirakan bernilai 4,4 persen produk domestik bruto (PDB), lebih dari sekedar sektor kehutanan, perikanan dan pertanian gabungan (4,1 persen). Ini dikatakan menjadi perkiraan konservatif karena banyak bentuk prostitusi tidak bisa dilacak, yang diperkirakan antara 1 dari 6 dan 1 dari 10 dari perempuan di negara ini telah bekerja dalam beberapa kapasitasnya dalam pelacuran (Hurt, 2005). Sedangkan industri seks di Belanda, yang telah melegalisasi pelacuran pada tahun 2001, diperkirakan bernilai 5 persen PDB (Daley, 2001).

Di China booming di industri pelacuran sejak bergerak menuju ekonomi pasar yang dimulai tahun 1978 dan seterusnya telah sangat terkenal karena telah berkembang dari basis yang rendah di era Maois saat prostitusi tidak ditolerir. Sekarang diperkirakan terdapat 200.000-300.000 wanita dilacurkan di Beijing sendiri dan dimana saja antara 10 sampai 20 juta wanita yang dilacurkan di China secara keseluruhan (Zhou, 2006). Industri pelacuran itu diperkirakan mencapai 8 persen dari ekonomi China, dan bernilai sekitar US \$ 700 miliar (Hurt, 2005).

Pemerintah seperti Filipina mendorong perdagangan ini dengan memberikan pelatihan untuk wanita sebelum mereka pergi. Pada tahun 2004 orang Filipina di Jepang mengirim pulang uang atau penghasilan mereka sekitar $\$ 258$ juta. \$ 8,5 miliar dalam pengiriman uang tahunan dari semua orang Filipina yang bekerja di luar negeri terdiri dari 10 persen dari 
pendapatan negara (McCurry, 2005, hal 15). Delapan puluh ribu orang Filipina memasuki Jepang pada tahun 2004 dengan visa hiburan enam bulan, dan Sekitar 90 persen harus bekerja dalam industri seks.

Di Indonesia, dan secara khusus di Jakarta, Ibukota negara, sumbangsih sektor hiburan sangat signifikan bagi pendapatan daerah ini dan telah berkontribusi besar dalam APBN melalui sektor pajak hiburan malam dan beberapa atribut bisnis lainnya yang terkait dengannya seperti minuman beralkohol, kondom, dan lainnya. Bahkan kebijakan Pemprov DKI Jakarta melalui Peraturan Daerah Nomor 13 Tahun 2010, sebagaimana telah diubah dengan Peraturan Daerah Nomor 3 Tahun 2015 tentang Pajak Hiburan, yang menerapkan tarif tertinggi untuk sektor ini, yakni sebesar 35 persen untuk panti pijat, mandi uap dan spa; serta tarif yang cukup tinggi sebesar 25 persen untuk diskotik, karaoke, klub malam, pub, bar, live music, musik dengan Disc Jockey (DJ) dan sejenisnya. Bahkan beberapa kota besar lainnya seperti Bandung dan Surabaya justeru meningkatkan tarif pajaknya untuk sektor ini, yang dengan begitu memberi kontribusi besar dalam peningkatan pendapat daerah dan nasional secara umum. Ini didukung dengan kebijakan pemerintah melalui lahirnya UU No. 28 Tahun 2009 Tentang Pajak dan Retribusi Daerah yang memungkinkan adanya pajak untuk sektor ini hingga 75 persen .

Lebih dari itu, globalisasi memungkinkan pornografi dan kejahatan terorganisir yang biasanya berhubungan dengan mereka, untuk menghasilkan keuntungan dari produk dan tempat di banyak negara. Industri seks tidak hanya menghasilkan keuntungan bagi pelacur, pemilik klub hiburan dan perusahaan pornografi. Banyak Aktor lain juga mendapatkan keuntungan secara ekonomi, yang membantu menanamkan prostitusi dalam ekonomi nasional (Poulin, 2005). Hotel dan maskapai penerbangan tentunya manfaat dari pariwisata seks, dan bisnis wisata seks. Sopir taksi yang mengantarkan pembeli laki-laki ke rumah pelacuran dan klub hiburan malam diberikan keuntungan ekonomi dari industri seks ini.

Orang lain yang juga diuntungkan dari industri ini adalah termasuk penjaga dan valets di klub hiburan, dan bisnis yang melayani penari telanjang dengan kostum dan make-up. Mereka juga termasuk perusahaan yang memasarkan minuman beralkohol yang dikonsumsi di dalam sebuah klub hiburan malam. Seperti misalnya dua perusahaan wiski Scotch, Chivas Regal dan Johnnie Walker, telah diidentifikasi sebagai penerima keuntungan dari bisnis pelacuran ini. Chivas Regal misalnya, mengalami pertumbuhan laba 12 persen di tahun 2004 disebabkan oleh keberadaan satu rumah bordil Thailand saja. Semua keuntungan ini dibuat dari penjualan tubuh wanita di pasaran, meski para wanita sendiri, menerima bagian yang sangat kecil dari keuntungan mereka.

Terlepas dari dampak negatif prostitusi terhadap kehidupan individu perempuan yang diksploitasi, ada kecenderungan untuk optimis dan berfikir positif terhadap kontribusi perempuan yang dilacurkan untuk 'pembangunan'. Lavenkron (2007) menyebutkan bahwa diskusi apapun tentang subjek pelacuran dan perdagangan perempuan, satu atau lebih dari mereka yang terlibat berpendapat, solusinya adalah melegalkan pelacuran. Mereka yang mendukung pendekatan ini mengklaim bahwa legalisasi akan memungkinkan unsur kriminal dapat diidentifikasi dan dihapus dari industri seks; akan melindungi hak wanita; dan akan mencegah gangguan publik. Mereka juga mengklaim bahwa negara akan mendapatkan keuntungan dari perpajakan industri seks (Nomi Lavenkron, 2007).

Sanghera misalnya membuat argumen bahwa perempuan yang dilacurkan berkontribusi pada pembangunan komunitas budaya yang lebih besar dengan membiayai pembangunan sekolah, tempat ibadah, kantor pos dan fasilitas pelayanan publik lainnya. Pengiriman uang mereka dari penghasilan luar negeri membantu pemerintah mereka melayani hutang negara '(Sanghera, 1997: 10). Pendekatan positif ini tidak menjadikan faktor bahaya pelacuran bagi kehidupan sosial dan ekonomi dari mereka yang dilacurkan. Tidak mempertimbangkan biaya yang mendukung gadis dan perempuan yang telah dirugikan bila melewati usia atau fisik dan masalah kesehatan mental mereka, manakala tidak lagi berharga bagi industri, biaya kepolisian dan pengoperasian sistem hukum yang terlibat dalam memerangi trafiking dan masalah lainnya seharusnya menjadi bagian integral industri ini yang harus diperhitungkan.

Pada akhirnya, kepentingan bisnis untuk kepentingan industri ini semakin berskala besar. Industri seks nasional dan industri seks dunia saat ini mengalami pertumbuhan dan tingkat keuntungan yang mengejutkan (IBISWorld, 2007; Poulin, 2005). Banyak masalah yang ada sekarang diakui secara intrinsik terkait dengan industri ini, merugikan kesehatan perempuan dan anak perempuan (Jeffreys, 2004), kejahatan terorganisir dan korupsi (M. Sullivan, 2007), perdagangan manusia (Farr, 2004; Monzini, 2005), seksualisasi dini anak perempuan (American Psychological Association, 2007).

Sedikitnya 12,3 juta orang dewasa dan anak-anak dibeli dan dijual di seluruh dunia ke dalam perbudakan seksual komersial (Ilo, 2005), Sekitar 2 juta anak dieksploitasi setiap tahun dalam perdagangan seks komersial global (Unicef, 2005). 8 dari 10 korban perdagangan teridentifikasi diperdagangkan karena eksploitasi seksual (UNODC, 2009). Perempuan dan anak perempuan merupakan $98 \%$ korban perdagangan manusia untuk eksploitasi seksual (Ilo, 2005).

Globalisasi industri seks, yang berarti bahwa terdapat pasar dalam tubuh seorang perempuan yang tidak lagi terbatas dalam batas-batas nasional. Perdagangan manusia, wisata seks dan bisnis perkawinanan telah memastikan bahwa ketidaksetaraan wanita yang parah dapat ditransfer di luar batas-batas nasional seperti yang dapat dilakukan oleh wanita miskin di negara-negara miskin yang dibeli secara seksual oleh pria dari negara-negara kaya (Belleau, 2003). dalam destinasi wisata seks mereka.

Industrilisasi seks merupakan diktum yang lahir melalui paradigma neo-liberal yang mengagungkan kebebasan melalui baragam cara yang eksploitatif. Kritik keras atas praktik ini terutama lahir dan keras didengungkan oleh kelompok aktivis feminis. Meskipun 
dalam kelompok aktivis feminis ini juga melahirkan beragam debat mengenai posisi perempuan khususnya terkait dengan konsep eksploitasi. Seperti misalnya posisi pekerja seks yang menarik perhatian feminis sosialis yang melihat prostitusi sebagai isu hak pekerja dan bukan kekerasan terhadap perempuan.

Teori dan tindakan feminis Sosialis kurang berfokus pada kekerasan perempuan dan lebih pada isuisu kerja dan ekonomi (Jeffreys, 1995). Bila beberapa kelompok kerja seks mengatakan bahwa pelacuran adalah pengalaman positif, pilihan tindakan pribadi dan seharusnya dilihat sebagai pekerjaan yang sah, beberapa orang merasa sulit untuk setuju atas argument tersebut. Kelompok Feminis Radikal misalnya di sisi lain, tidak siap untuk melihat pelacuran sebagai pekerjaan biasa karena fokus mereka pada kekerasan terhadap perempuan, khususnya kekerasan seksual. Mereka mengenali adanya kesamaan antara pengalaman perempuan yang dilacurkan dan korban pemerkosaan, seperti harus melepaskan diri secara emosional dari tubuh mereka untuk bertahan hidup, dan menderita gejala shock pasca trauma dan perasaan negatif tentang tubuh dan diri mereka (Jeffreys, 1997; Farley, 2003).

\section{METODE}

Jenis penelitian ini ialah studi pustaka (desk research), jenis penelitian ini ialah kualitatif dengan menghasilkan data deskriptif. Bogdan dan Taylor dalam Moleong (2000) menyatakan bahwa "Metode kualitatif sebagai prosedur penelitian yang menghasilkan data deskriptif berupa kata-kata tertulis atau lisan dari orangorang dan perilaku yang dapat diamati”. Penelitian ini menggunakan beberapa dokumen seperti buku, jurnal ilmiah, artikel ilmiah dan populer sebagai referensi utama dalam memperoleh data utama dan menganalisis data tersebut.

Penelitian ini menggunakan analisis data interaktif. Miles dan Huberman (1992) yang memberikan 4 (empat) tahap analisis data yaitu :

1. Pengumpulan data, yaitu mengumpulkan semua data.

2. Reduksi data, merupakan proses pemilihan dan penyortiran data.

3. Penyajian data, peneliti dapat melihat data yang diperoleh secara utuh.

4. Penarikan kesimpulan dilakukan secara induktif

\section{HASIL DAN PEMBAHASAN}

\section{Faktor Yang Kompleks: Kebijakan, Teknologi, Ekonomi dan Budaya}

Ada tiga atribut teoritis yang dapat digunakan untuk menjelaskan perdagangan manusia untuk eksploitasi seksual terhadap perempuan dan anak perempuan muda yakni: kerentanan korban, pengendapan korban, serta hubungan kriminal korban (Daems, 2005; Nettlebeck, Wilson, Potter \& Perry, 2000). Atribut ini harus ada dan stabil dalam kehidupan korban sejak lama (Nettlebeck et.al 2000). Kerentanan korban berkaitan dengan adanya faktor, kontekstual dan situasional, dalam kehidupan korban yang bisa membuat korban lebih rentan terhadap praktik ini (Clark, 2005). Bisa jadi gaya hidup korban; karakteristik pribadi atau jumlah waktu korban menghabiskan atau berinteraksi dengan pelaku (UNICEF, 2003; UNODC, 2007).

Kerentanan korban paling baik dijelaskan saat seseorang dikelilingi oleh faktor-faktor yang bisa berakibat dalam viktimisasi. Hal ini disebabkan oleh berbagai faktor internal dan eksternal yang multidimensi, seperti usia dan kurangnya kedewasaan, yang mempengaruhi wanita muda dan anak perempuan lebih dari orang dewasa, sementara faktor sosial ekonomi menciptakan potensi korban baik untuk anak dan orang dewasa (Clark, 2005).

Studi yang dilakukan Lutya (2012) menunjukkan bahwa banyak wanita dan gadis muda (dalam kasus di Afrika Selatan) menghabiskan waktu luang mereka di tempat hiburan untuk menjual minuman keras (klub malam dan bar), menyalahgunakan zat-zat yang memabukkan seperti obat-obatan terlarang dan alkohol, terlibat dalam perilaku seksual berisiko, serta berpartisipasi dalam kegiatan kriminal (Gould, 2005; Gould \& Fick, 2008). Gaya hidup ini menempatkan mereka sangat dekat dengan para pedagang manusia. Situasi kontekstual di mana gadis menghibur diri mereka sendiri, ditambah dengan ketidakmatangan mereka dan tidak adanya kontrol dari keluarga mereka, dapat mempermudah para pedagang untuk merekrut mereka dengan sukses.

Perilaku eksentrik oleh seorang korban potensial tidak harus menciptakan kerentanan terhadap korban, tapi miskinnya kontrol atas sensitifitas perasaan, keterampilan sosial yang tidak memadai dan tanggapan konfrontatif terhadap situasi yang bermasalah dapat meningkatkan kerentanan terhadap korban (Nettlebeck et al, 2000). Terlepas dari karakteristik pribadi, gaya hidup korban dan beberapa perempuan muda dan anak perempuan yang menghabiskan waktu dengan pedagang manusia, faktor kontekstual dan situasional seputar korban juga membuat mereka rentan terhadap perdagangan manusia untuk dieksploitasi secara seksual.

Faktor tersebut mendorong sebagian besar remaja putri dan anak perempuan untuk melakukan kejahatan dan pergaulan bebas (seperti kondisi rumah dan keluarga yang tidak menguntungkan, termasuk kurangnya pengawasan dan pemantauan orang tua, kekerasan antar orang tua, kekerasan saudara dan penggunaan zat yang memabukkan) yang dikombinasikan dengan tantangan sosial ekonomi, adalah turut memperburuk kerentanan wanita muda dan anak perempuan terhadap pedagang manusia (Clark, 2005; Lutya, 2010b; Lutya, 2007).

Sebelum menerima pekerjaan dari seorang pedagang manusia, biasanya korban sering dihadapkan dengan kondisi dan tantangan individu, sosio-ekonomi seperti pengangguran dan kemiskinan, kekerasan dalam rumah tangga, kurangnya pengetahuan tentang kejahatan, stereotip dan persepsi tentang pelacur, serta faktor sosial budaya yang menghambat akses terhadap peluang untuk 
kemajuan ekonomi. Dihadapkan dengan faktor-faktor tersebut, mereka mungkin menerima (tidak ada) kesempatan yang mereka percaya bisa menyelamatkan mereka dari konteks keterpurukan ini, yang pada gilirannya, mereka membuka peluang untuk dieksploitasi secara seksual. Bahkan, perdagangan manusia bisa jadi adalah orang yang dipercaya oleh korban, seperti teman dekat, anggota keluarga, agen tenaga kerja atau tetangga (Lutya, 2009; O'Connor, 2009 \& Prince, 2009).

Dengan demikian, secara umum bahwa perdagangan manusia untuk kepentingan eksploitasi seksual melalui jalur internal dan eksternal. Alasan eksternal adalah alasan yang secara jelas dapat dilihat dari kepentingan industri pelacuran dan perdagangan manusia untuk mengambil keuntungan dari aktivitas pelacuran baik dalam skala kecil maupun besar. Sedangkan alasan internal dapat dilihat pada aspek kebudayaan, ekonomi, pengawasan dalam lingkungan keluarga dan sosial, serta kebijakan dan hukum yang lemah. Bahkan para pedagang manusia seringkali menargetkan perekrutan terhadap anak usia dini karena adanya preferensi klien untuk gadis muda - klien seperti itu percaya bahwa gadis yang lebih muda patuh dan jinak, dan karena itu lebih cenderung memenuhi tuntutan seksual mereka (Bernat \& Zhilina, 2010; Bernant \& Winkeler, 2010; UNICEF 2003).

Lebih dari itu, meningkatnya profitabilitas dan perluasan industri seks global tergantung penerimaan sosial (dan konteks ekonomi-politik yang luas juga kebijakan publik). Kebijakan publik ini berkenaan dengan berbagai aspek yang saling terhubung dan terintegrasi dalam industri seks, baik melalui kebijakan teknologi, kebijakan pembangunan ekonomi dan kebijakan sosial lainnya yang memberikan advokasi kepada kelompok perempuan dalam berbagai akses sumberdaya sosial publik seperti pendidikan, ekonomi, dan kesehatan. Seperti dalam banyak kasus yang dijumpai, minimnya lapangan kerja bagi perempuan di ruang publik, mengharuskan mereka untuk bekerja di luar negeri.

Dalam catatan sejarahnya, bahwa aktivitas perdagangan ini telah dimulai sejak masa kolonial. Sebagaimana dicatat Lutya (2012) dalam kajiannya di Afrika Selatan bahwa sebuah organisasi hak anak "Molo Songololo" tahun 2005 melaporkan bahwa antara tahun 1726 dan 1834, sebanyak 36.169 budak dibawa dari Indonesia, Jawa, Ceylon, India, Hindia Timur, Mauritius, Malaysia dan negara-negara lain ke Afrika Selatan untuk bekerja di pertambangan, dan sebagai pekerja rumah tangga. Di era modern, salah satu alasan model perekrutan untuk perdagangan orang adalah rekrutmen, dengan janji kemakmuran ekonomi dan kemajuan pendidikan, yang pada akhirnya berujung pada eksploitasi seksual untuk kelompok rentan seperti perempuan dan anak-anak gadis. Selain itu, semakin banyak Infeksi HIV / AIDS telah mempopulerkan mitos sosio-kultural penyembuhan melalui darah keperawanan (Dyantyi \& Pritz, 2009; Fitzgibbon, 2003; Gould, 2008).

Lebih dari itu, Lutya (2012), melihat bahwa perdagangan perempuan untuk kepentingan industri seks, seringkali terjadi melalui konteks kebudayaan, utamanya budaya hedonism. Ini misalnya bisa dilihat darikeinginan untuk memiliki label terbaru dan gadget teknologi mendorong beberapa gadis untuk mengejar harapan materialistis mereka. Jika ditawarkan pekerjaan, gadisgadis seperti itu bisa menerima pekerjaan itu dengan sedikit atau tanpa pengawasan dengan harapan agarsebuah pendapatan untuk mencapai tujuan materialistik tersebut dapat terwujud (Lutya, 2010a). Mungkin saja perlu untuk mencapai konsep feminin berdasarkan gender yang disetujui oleh patriarkhi, yang didefinisikan secara aesthetics - pakaian mewah, make-up, rambut dan kuku yang rapi - serta keinginan untuk menyesuaikan diri dan menerima konfirmasi eksternal (Russell \& Tyler, 2002) dapat mendorong beberapa gadis untuk menerima pekerjaan yang meragukan dari para pedagang manusia yang datang ke rumah-rumah mereka.

Jenis kelamin dan konsumsi bisa menjadi cara yang didefinisikan beberapa anak perempuan siapa mereka dalam hubungan dengan anak laki-laki dan masyarakat: itu berarti mereka menjadi feminin melalui Budaya konsumerisme, perilaku masyarakat mengharapkan remaja putri dan anak perempuan (Russell \& Tyler, 2002). Intinya, setiap orang yang berusia di bawah 18 tahun rentan terhadap perdagangan manusia di beberapa negara melalui beberapa cara: secara ekonomi dan kebijakan. Dalam konteks kebijakan kesehatan misalnya, Vektor utama bahasa neo-liberal dalam kaitannya dengan prostitusi adalah badan kerja seks yang dibentuk atau didanai oleh pemerintah untuk menyediakan kondom untuk wanita dan pria yang dilacurkan terhadap transmisi HIV.

Kamala Kempadoo, seorang peneliti penting di bidang pariwisata seks dan pelacuran di Karibia, mengatakan: "beberapa pekerjaan pencegahan AIDS telah berkontribusi untuk pembentukan organisasi pekerja seks baru, secara tidak sengaja memberdayakan pekerja seks di daerah lain selain hanya dalam urusan kesehatan" (Kempadoo, 1998, hal 19). Dengan munculnya dana AIDS, aktivis pekerja seks mendapatkan platform dan otoritas, sebagai ahli dalam krisis kesehatan masyarakat yang seharusnya (B. Sullivan, 1994).

Lebih dari itu, perkembangan teknologi baru seperti perjalanan udara telah memfasilitasi pergerakan perempuan dan anak perempuan yang dilacurkan dan pembeli sehingga meningkatkan skala dan lingkup internasional industri ini. Demikian juga internet telah memungkinkan pariwisata seks, bisnis online pengantin wanita dan bentuk pelacuran lainnya untuk berkembang dan saling terkait. Teknologi Elektronik baru dari rekaman video ke Internet telah memungkinkan pengembangan industri yang menguntungkan secara besar-besaran dengan jangkauan global, di mana wanita di negara miskin dapat dikirim dalam film atau melalui real time untuk melakukan adegan seks untuk memuaskan pria di barat (Hughes, 1999).

Pelacuran juga diglobalkan melalui proses pembangunan ekonomi di negara-negara yang subsisten. Pelacuran, atau dalam beberapa kasus bentuk pelacuran tertentu, diekspor ke lokasi pengembangan industri di negara-negara 'miskin' seperti Papua Nugini dan Kepulauan Solomon (Wardlow, 2007; UNESCAP, 2007). 
Jadi sebagai penambangan dan pembalakan perusahaan asing dalam membuka area baru sebagai bentuk baru eksploitasi kolonial mereka mendirikan industri pelacuran untuk melayani para pekerja.

Industri ini memiliki pengaruh besar terhadap budaya dan hubungan lokal antara pria dan wanita. Praktik ini memiliki sejarah dalam 'perkembangan' dari Australia pada abad ke-19, misalnya, ketika perempuan Aborigin atau perempuan Jepang yang diperdagangkan atau dipekerjakan untuk melayani orang yang terlibat dalam mengambil alih tanah adat untuk pertambangan dan ternak pertanian (Frances, 2007).

\section{Kebijakan Legalisasi Pelacuran dan Perbaikan Institusional Pelayanan Sosial}

Pertama-tama, pendekatan atau perspektif dalam melihat pelacuran dapat dilihat melalui pendekatan religius atau konservatif yang memandang pelacuran sebagai sebuah masalah moral dan penyimpangan yang berbahaya; Asumsi yang mendasari pendekatan ini adalah bahwa memungkinkan untuk memberantas pelacuran melalui penegakan hukum tanpa kompromi; Dengan demikian, pendekatan ini cenderung mendukung kriminalisasi semua pihak yang terlibat dalam fenomena tersebut. Namun, ini memerlukan biaya ekonomi yang mahal dan belum terbukti efektif dalam menghilangkan fenomena pelacuran dalam jangka panjang (Reynolds, 1986).

Bahkan kriminalisasi perempuan yang terlibat dalam prostitusi akan mencegah mereka untuk mengeluh kepada pihak berwenang jika mereka adalah korbannya; berkontribusi terhadap stigmatisasi negatif mereka; dan memberi batas lebih lanjut mengenai kemungkinan untuk membantu wanita melepaskan diri dari jeratan pelacuran. Sejalan dengan ini adalah pendekatan ini adalah pendekatan feminis radikal yang juga berusaha membatasi fenomena pelacuran, meski berfokus pada kepentingan kelompok perempuan yang dibelanya. Pendekatan ini memandang pelacuran sebagai mekanisme untuk penindasan sosial dan eksploitasi perempuan.

Prostitusi adalah salah satu konsekuensi dari trauma yang mereka alami, dan Ini menambahkan kerusakan fisik dan psikologis lebih lanjut (Farley dan Barkan, 1998). Pendekatan ini memandang pelacuran sebagai institusi yang mempermalukan semua wanita di dalam masyarakat, mempertahankan citra mereka sebagai objek seks, dan melestarikan ketidaksetaraan di antara pria dan wanita. Pendekatan ini menentang kriminalisasi perempuan dalam prostitusi dan menganjurkan kriminalisasi terhadap mereka yang memanfaatkan mereka. Pendekatan ini sangat menentang legalisasi pelacuran meskipun dengan alasan yang berbeda dari yang disajikan oleh pendekatan konservatif. Feminis Radikal berpendapat bahwa legalisasi prostitusi adalah analog pemberian lisensi untuk mengeksploitasi perempuan.

Legalisasi akan menguntungkan laki-laki dan melemahkan status perempuan lebih jauh - terutama perempuan yang bekerja di sektor prostitusi. Dan secara lebih jauh, legalisasi ini akan menarik lebih banyak wanita dan korban yang lebih banyak ke dalam industri seks, melemahkan motivasi pihak berwenang untuk bertindak melawan pelanggaran hak asasi manusia (terutama perempuan yang dieksploitasi) yang menyertai pelacuran itu sedniri. Ini akan mengarah pada perluasan industri seks, memperkuat status mucikari dan klien dengan mengorbankan perjuangan terhadap kerusakan dan korban dari fenomena ini. Mereka menilai bahwa Industri pelacuran yang dilegalkan atau didekriminalisasi merupakan salah satu akar penyebab dari perdagangan seks (Raymond, 2003).

Pendekatan lainnya adalah pendekatan liberal yang menerima pelacuran sebagai bagian dari kehidupan yang sah dan menekankan hak perempuan untuk memilih bekerja pada pelacuran sebagai "profesi yang tertua di dunia" ini. Pendekatan ini berpendapat bahwa tidak mungkin untuk memerangi pelacuran, dan mengkritik pendekatan konservatif karena bertopeng kemunafikan dan cenderung untuk mengabaikan masalah, dan hanya memperburuk paksaan dan eksploitasi yang menyertai pelacuran. Pendekatan Liberal berpendapat bahwa legalisasi dimaksudkan untuk memenuhi kebutuhan alamiah pria yang memang harus dipenuhi, asalkan hal ini terjadi tanpa paksaan.

Legalisasi pelacuran akan mengurangi kerugian yang terjadi dalam pelacuran dan menawarkan sejumlah keuntungan: Mereka yang bekerja di bidang Pelacuran akan menjadi orang dewasa yang melakukannya dengan pilihan mereka sendiri, tanpa eksploitasi anak di bawah umur dan korban trafiking; stigma sosial Pelacuran yang menyertainya akan dihapus dan wanita-wanita yang terlibat akan melakukannya untuk dapat hidup tanpa rasa malu; negara akan menerima penghasilan dari pajak; kesehatan masyarakat akan lebih terlindungi; pelacuran akan dibatasi dan akan menimbulkan sedikit gangguan pada masyarakat umum; dan kondisinya di mana wanita bekerja akan meningkat (Nomi Levenkron, 2007).

Pendekatan pekerja seks mengkritik pendekatan feminis radikal. Pendekatan pekerja seks mendukung penghapusan hukum pembatasan yang berkaitan dengan prostitusi, namun menekankan hak-hak perempuan yang terlibat sebagai pekerja, bukan perlindungan klien atau keuntungan mucikari. Pendekatan ini berpendapat bahwa pilihan perempuan untuk bekerja sebagai pelacur harus dihormati meski itu karena keterbatasan kesempatan, dan lebih suka melihat wanita yang pindah ke negara lain untuk bekerja pada industri seks sebagai migran daripada harus menjadi korban trafiking (Agustin, 2005).

Pendekatan ini berpendapat bahwa perempuan yang terlibat harus diberi hak justru karena mereka tunduk pada kekerasan dan harus diaktifkan untuk melindungi diri mereka sendiri (Ostergren, 2004). Meskipun begitu, seperti halnya kelompok feminis radikal, pekerja seks menentang adanya pelembagaan, atau setidaknya beberapa pembatasan yang dimilikinya. Menurut Nomi (2007) bahwa Setiap kebijakan prostitusi mencerminkan salah satu pendekatan tersebut diatas dan dipengaruhi oleh faktor politik, ekonomi, dan faktor sosial dalam konteks lokal di mana kebijakan itu lahir. 
Seperti halnya kebijakan legalisasi, bahwa untuk memahami bagaimana legalisasi beroperasi dalam bentuk apapun yang diberikan oleh negara, harus dianalisis dalam konteks sosial, politik, dan konteks ekonomi.

Legalisasi dapat diterapkan dengan berbagai variasi bentuk ukuran peraturan dan pengawasan, yang masing-masing memiliki konsekuensi. Berdasarkan studi evaluasi terhadap kebijakan legalisasi pelacuan yang dilakukan di Nevada, Jerman, Belanda, dan Australia menunjukkan bahwa legalisasi belum bisa mencapai semua tujuannya, atau tujuan utamanya, diantaranya dalam kontribusinya untuk membina toleransi sosial prostitusi; Legalisasi belum mengubah stigma yang melekat pada prostitusi; Bersama dengan keengganan membayar pajak, stigma ini merupakan salah satu faktor utama menghalangi perempuan mendaftarkan diri sebagai pekerja prostitusi; legalisasi juga tidak serta merta meningkatkan kesehatan pekerja seks, karena kenyatannya bahwa klien dari industri seks adalah kebanyakan dari mereka yang mengonsumsi seks dengan membeli adalah para pria yang sudah menikah atau pria lajang yang berhubungan seks dengan sejumlah besar wanita dan bukannya pria muda yang kesepian.

Lebih dari itu, dapat dipahami bahwa legalisasi pelacuran sebagai instrumentalis-kapitalis yang berfokus pada usaha oleh negara untuk mendapatkan keuntungan dari industri seks. Jenis legalisasi ini akan menyebabkan pemberian lisensi ke rumah pelacuran, dan bukan kepada pelacur; pelacuran hanya legal di dalam rumah pelacuran dan bukan di tempat lain selain yang dilegalkan pemerintah atau negara. Pada akhirnya, berdasarkan evaluasi terhadap konsekuensi praktis dari legalisasi pelacuran menunjukkan bahwa tujuan utamanya dari kebijakan ini penghapusan perdagangan perempuan, memperbaiki kesehatan, dan memastikan mereka menikmati hak - telah gagal total atau, paling banter, hanya sukses sebagian. Legalisasi telah ditunjukkan hanya memberikan perlindungan terbatas untuk wanita, dan umumnya hanya untuk wanita yang memilih bekerja dalam pelacuran atas kehendak bebas mereka sendiri. Dan pada akhirnya apa yang harus ingat dari kebijakan legalisasi ini bahwasanya industri seks akan selalu lebih kuat dari wanita yang dijebaknya.

\section{Relasi Prostitusi dan Kekuasaan}

Terkait dengan ini, Christenson (2013) mengatakan bahwa prostitusi adalah tentang seksualisasi kekuasaan. Kekuasaan berdasarkan jenis kelamin, kekuasaan berdasarkan kelas, kekuasaan berdasarkan etnisitas. Pelacuran ada, seperti halnya segala hal lainnya, dalam sebuah konteks. Pada gilirannya, pelacuran juga mempengaruhi masyarakat - terutama pandangan masyarakat tentang gender. Prostitusi berawal dari tradisi seksual puritan, dimana hanya seksualitas pria yang dihitung. Pelacuran didasarkan pada seksualitas pembeli.

Alasan mengapa orang yang dilacurkan mendapat uang, adalah bahwa "seks" dalam pelacuran itu secara eksklusif ditentukan oleh pembeli. Semua bentuk pelacuran itu berdasarkan ide yang sama: pelaku prostitusi membeli akses seksual ke tubuh orang lain--untuk menggunakannya sesuai dengan cara dia membayarnya. Pembeli adalah dasar dari semua prostitusi. Pelacuran ada karena pelacur telah menyalurkan seksualitas mereka menjadi satu sisi konsumsi. Mereka mengklaim hak untuk menggunakan orang lain - yang kebutuhan dan keinginan seksualnya "dihapus" oleh pembayaran pelaku. Dan semua bentuk prostitusi memiliki persamaan dalam mempengaruhi pandangan masyarakat terhadap perempuan.

Oleh karena itu, kita perlu diingatkan kembali pada satu laporan dari PBB dari tahun 2009, mencakup 155 negara, yang menunjukkan bahwa sekitar $79 \%$ dari semua perdagangan manusia di dunia adalah untuk tujuan seksual. Prostitusi menyabotase seksualitas berdasarkan nafsu. Prostitusi adalah bagian dari objektivikasi perempuan dan komersialisasi / reifikasi seks. Sehingga menjadi jelas bahwa melegalkan pelacuran adalah bahasa lain dari penindasan dan kolonialisasi.

Lebih dari itu, orang-orang dalam pelacuran lebih rentan terkena risiko yang tinggi menderita kekerasan fisik dan psikologis yang parah dan bahkan risiko kematian yang besar (Farley, 2004). Bahkan berkenaan dengan perbedaan prostitusi outdoor dan indoor, berbagai penelitian menemukan bahwa tingkat kekerasan sebanding, dan dalam beberapa kasus lebih besar di dalam rumah daripada di luar rumah (Transcrime, 2005).

\section{Peran Lingkungan dan Kebijakan Pendidikan}

Dari aspek penegakan hukum misalnya, Kurangnya posisi hukum yang pasti mengenai tindakan pelacuran menciptakan kebingungan dalam penerimaan aktivitas ini. Meskipun beberapa asumsi normatif sering didengungkan bahwa pelacuran, menjalankan rumah pelacuran, memaksa seseorang untuk bekerja sebagai pelacur dan mendapatkan penghasilan dari pelacuran adalah kegiatan kriminal. Meski demikian, sangat mungkin bagi petugas atau aparatur negara, bukan untuk menangkap pelacur di jalanan, tapi untuk mengintimidasi mereka, menginterogasi mereka dan mengizinkannya mereka untuk melanjutkan aktivitas malam hari (Fick, 2007).

Rumah pelacuran yang dirazia mungkin ditutup sementara dan kemudian mungkin diizinkan untuk melanjutkan operasi mereka pada saat aparat kepolisian meninggalkan tempat itu (Gould \& Fick, 2008). Bahkan di beberapa tempat di Indonesia masih semacam malumalu melegalkan lokalisasi, meskipun beberapa diantaranya seperti praktik prostitusi di Doly Surabaya telah ditutup melalui kebijakan pemerintah Kota Surabaya. Di kota-kota lainnya juga terlihat seperti penutupan lokalisasi Kalijodo di Jakarta. Lebih dari itu, tanpa kebijakan sosial lainnya maka upaya penutupan lokalisasi pelacuran seakan hanya memindahkan atau merelokasi pelacuran.

Dari aspek ini masalah ini semakin diperkuat dengan minimnya pelayanan sosial bagi anak terlantar. Meskipun telah ada lembaga sosial bagi upaya pemberdayaan anak dan perempuan masih belum 
terintegrasi dalam sebuah sistim sosial yang efektif dalam penanggulangannya. Pemerintah dan pemerintah daerah yang membidangi masalah ini seakan hanya melakukan pendataan dari tahun ke tahun tanpa intervensi kebijakan sosial yang efektif

\section{PENUTUP}

\section{Simpulan}

Pembinaan dan pengawasan oleh Dinas sosial masih kurang efektif dalam menyelesaikan persoalan ini. ini terutama terlihat dari tidak terintegrasinya berbagai kebijakan nasional dan daerah. Bahkan beberapa daerah belum membuat sebuah kerangka regulasi dalam penanganan masalah sosial di daerah saat ini. padahal, masalah sosial seperti kekerasan seksual dan perdagangan manusia untuk kepentingan industri seksual korbannya adalah banyak dari kalangan pedesaan, di mana mereka direkrut dan dieksploitasi untuk kepentingan industri.

Kebijakan di daerah selayaknya sejalan dengan program global penanggulangan perdagangan perempuan dan anak untuk kepentingan seks dengan merancang program yang menawarkan dukungan emosional dan praktis, termasuk perawatan kesehatan, bantuan hukum, dan bantuan psikologis (APA, 2014). Program ini dirancang untuk melakukan beberapa hal seperti: memberdayakan pekerja seks muda untuk bernegosiasi untuk memperbaiki kondisi kerja, memberikan para pekerja keterampilan untuk menghemat uang, membantu mereka mencari pilihan pekerjaan alternatif. Selain itu juga, dapat dengan melatih mereka untuk bertindak sebagai pendidik bagi teman sebaya mereka untuk menjangkau perempuan lain yang berisiko untuk diperdagangkan.

Program dan kebijakan termasuk didalamnya adalah Kebijakan Pencegahan (Sosialisasi dan penanganan masalah sosial yang luas: kebudayaan, ekonomi dan politik); Kebijakan perlindungan dengan mengidentifikasi, pelaporan dan rujukan adalah beberapa tindakan perlindungan yang dapat diterapkan untuk menanggapi praktik perdagangan manusia; Kebijakan Penuntutan, di mana akses terhadap hukum dan membuat jera pelaku kejahatan seksual; Kebijakan Afirmasi, yakni dengan memberikan akses kepada perempuan dalam ruang publik, seperti lingkungan politik dan partisipasi perempuan dalam implementasi kebijakan ekonomi dan sistim politik; dan partnership.

Minimnya akses pendidikan dan kesempatan kerja ini menjadi masalah besar saat ini di mana jumlah perempuan yang semakin besar berikut lapangan pekerjaan yang memungkinkan bagi mereka akan sangat sulit. Ini berdampak pada posisi perempuan dalam pekerjaan yang menguras fisik untuk ditempatkan sebagai penghibur. Wanita kemudian seakan menjadi objek seksualitas untuk diperdagangkan. Dalam kasus industri seks di Indonesia, di mana masih bersifat tertutup, semi formal yang dibungkus melalui praktik hiburan malam, panti-panti pijat dan semacamnya telah menyeret perempuan-perempuan berparas cantik untuk direkrut dan dipekerjakan pada industri tersebut.

Beberapa dari mereka yang direkrut di daerahdaerah terpencil di sudut-sudut kota untuk dipekerjakan di Industri hiburan dan refleksi di Jakarta dan beberapa kota besar di Indonesia. Khusus untuk industri refleksi misalnya karena membutuhkan beberapa skil tambahan seperti kemampuan melakukan pijatan diberi pelatihan dan Pendidikan khusus mengenai keahlian tersebut. Senyatanya, kelebihan fisik berupa paras cantik mendorong perempuan untuk diobjektifikasi menjadi industri seks bagi kelompok pengusaha-pengusaha yang melihat peluang tersebut secara ekonomi.

Sedangkan dalam kasus pelacuran sukarela, dimana sebagai contoh kecil yang telah kita amati di daerah lokasi pertambangan rakyat (emas) di Kabupaten Bombana pada tahun 2008-2009. Posisi perempuan yang tidak bisa melakukan kegiatan pertambangan rakyat dengan melakukan aktivitas seperti pendulangan biasanya bekerja sebagai pelacur di area tersebut, yang seringkali bayaran atas pelayanan seks yang diberikan kepada penambang pria bisa berupa pertukaran dengan emas yang dihasilkan dari proses pendulangan (Sekitar 1 Gram untuk sekali pelayanan seks).

Tentunya, ini bukanlah gambaran yang mendeskripsikan seluruh wanita yang berada di areal tersebut bekerja sebagai pelacur, melainkan umumnya secara khusus datang ke tempat tersebut untuk tujuan sebagai pekerja seks. Mereka umumnya datang dari luar daerah Bombana seperti Manado dan Jakarta serta Pulau Jawa. Pekerjaan mereka yang selama ini terjebak dalam industri seks di daerah asalnya menangkap peluang tersebut untuk memperoleh manfaat secara ekonomi.

Keberadaan tambang yang memicu geliat ekonomi kemudian menjadi semacam areal pelacuran informal. Bahkan dalam beberapa kasus lain yang dijumpai seperti halnya di Konawe dalam pengelolaan tambang nikel di PT. Morosi, yang melibatkan tenaga kerja asing asal china-tiongkok. Berbeda dengan di Bombana, eksploitasi perempuan adalah melalui perkawinan kontrak. Tenaga kerja asal Tiongkok menikahi wanita-wanita lokal setempat untuk memenuhi kebutuhan biologis mereka.

Minimnya lapangan kerja, konteks budaya yang luas seperti konsumerisme adalah menjadi andil dan berperan dalam praktik perkawinan kontrak seperti ini. Bahkan beberapa kalangan lokal mengatakan bahwa model perkawinan ini menjadi semacam bentuk kolonialisasi gaya baru demi memperkuat posisi penjajahan ekonomi asing atas sumberdaya lokal. Dalam hal ini, eksploitasi asing di daerah miskin tidak hanya berupaya menguras sumberdaya alam-nya saja melainkan juga sumberdaya manusia mereka melalui penjajahan seksualitas.

\section{Saran}

Peran eksekutif dan legislatif sangat diperlukan dalam pembuatan kebijakan pendidikan, beberapa hal yang seharusnya menjadi perhatian serius adalah (a). masalah materi dan orientasi Pendidikan (b). masalah 
biaya Pendidikan yang tinggi. Pertama, materi dan oreintasi Pendidikan yang terlepas dari perspektif kritisnya dan dalam upaya pembentukan kesadaran baik psikis dan mental dan contong pada orientasi pragmatis untuk kepentingan pekerjaan tertentu mendorong peserta didik untuk menjadikan Pendidikan sebagai sarana pencapaian maksud dan tujuan materialistis. Kedua, mahalnya biaya Pendidikan saat ini selain berdampak pada sulitnya akses ke Pendidikan formal sekaligus berdampak pada pola pikir peserta didik dalam menyesuaikan dengan sistim Pendidikan yang berlaku saat ini, sehingga tidak sedikit perempuan dari kalangan peserta didik saat ini berpofesi ganda untuk menjadi pelacur yang sering disebut sebagai "ayam kampus" dalam rangka memenuhi kebutuhan perkuliahan yang membebani disaat kelompok pelajar atau peserta didik pria bekerja paruh waktu baik sebagai buruh maupun jenis kerja kasar lainnya.

Sejatinya, tantangan tersebut menjadi masalah yang seharusnya dapat terselesaikan melalui kebijakan pendidikan yang pro-pada kepentingan publik dan bukannya industri pendidikan. Bahkan tidak sedikit lahirnya perguruan-perguruan tinggi swasta saat ini didorong karena adanya tujuan untuk memperoleh keuntungan melalui industri Pendidikan dengan menawarkan jalan pintas untuk memperoleh ijazah dan memberikan kelulusan dengan mudah tanpa standar yang ditetapkan pemerintah melalui kementerian Pendidikan nasional maupun perguruan tinggi.

\section{DAFTAR PUSTAKA}

Christenson, Gerda (2013). Speaking of Prostitution, The Women's front, 2013.

Daley, S. (2001). 'New Rights for Dutch Prostitutes, but No Gain'. New York Times, 12 August.

Defeis, Elizabeth F. (2000). 'Draft Convention Against Sexual Exploitation'. In Askin, Kelly D. and Koenig, Dorean M (eds), Women and International Human Rights Law, Vol. 2. New York: Transnational Publishers, Inc., pp. 319-48.

Hurt, Michael (2005). 'Sex Business Lives on Despite Crackdown'. Korea Herald, 27 May.

Hughes, Donna M. (1999). 'The Internet and the Global Prostitution Industry'. In Hawthorne, Susan and Klein, Renate (eds), Cyberfeminism. Connectivity, Critique and Creativity. Melbourne: Spinifex, pp. 157-84.

Hammond, Claudia (2008). 'I'm Just Here for Survival'. Guardian, 9 January. International Labour Organization (n.d.). Main Aims. Home page of the ILO; http://www.ilo.org/global/index.htm.

Jeffreys, Sheila (1995). 'Representing the Prostitute'. Feminism and Psychology, 5: 539-42.

Jeffreys, Sheila (1997). The Idea of Prostitution. Melbourne: Spinifex.
Jeffreys, Sheila (1999). 'Globalising Sexual Exploitation: Sex Tourism and the Traffic in Women'. Leisure Studies, 18: 179-96.

Jeffreys, Sheila (2009). The Industrial Vagina: The political economy of the global sex trade, Routledge, Milton Park, Abingdon.

Laporan Tahunan Perdagangan Orang 2016, Kedutaan Besar dan Konsulat AS di Indonesia. Diunduh melalui: $\quad$ https://id.usembassy.gov/id/ourrelationship-id/official-reports-id/laporan-tahunanperdagangan-orang-2016/. Diakses tanggal 27 September 2017.

Lim, Lin Lean (ed.) (1998). The Sex Sector. The Economic and Social Bases of Prostitution in Southeast Asia. Geneva: International Labour Office.

Lutya, Thozama Mandisa (2012). Human Trafficking of Young Women and Girls for Sexual Exploitation in South Africa, InTech.

Millett, Kate (1972). Sexual Politics. London: Abacus, Sphere Books.

Millett, Kate (1975). The Prostitution Papers. St Albans: Paladin.

Moon, Katharine S. (1997). Sex Among Allies. Military Prostitution in U.S.-Korea Relations. New York: Columbia University Press.

Sullivan, Barbara (1994). 'Feminism and Female Prostitution'. In Perkins, Roberta and Prestage, Garrett (eds), Sex Work and Sex Workers in Australia. Sydney: University of New South Wales Press.

Sullivan, Mary (2007). Making Sex Work: The Failed Experiment of Legalized Prostitution in Australia. Melbourne: Spinifex.

Zhou, M. and Bankston, C.L. (1994). Social Capital and the Adaptation of the Second Generation: The Case of Vietnamese Youth in New Orleans. International Migration Review, 18 (4): 821-845. 